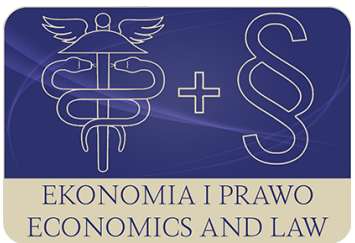

EKONOMIA I PRAWO. ECONOMICS AND LAW

Volume 20, Issue 4, December 2021

p-ISSN 1898-2255, e-ISSN 2392-1625

www.economicsandlaw.pl

EKONOMIA I PRAWO
ECONOMICS AND LAW

ORIGINAL ARTICLE

received 31.05.2021; revised 01.12.2021; accepted 31.12.2021

Citation: Smolny, K., \& Gałecka, M. (2021). The productivity of performing art organisations versus

labor costs. Ekonomia i Prawo. Economics and Law, 20(4), 847-860. https://doi.org/10.12775/EiP.2021.050.

\title{
The productivity of performing art organisations versus labor costs
}

\author{
KATARZYNA SMOLNY \\ corresponding author \\ Wroclaw University of Economics and Business, Department of Finance, \\ ul. Komandorska 118/120, 53-345 Wroctaw, Poland \\ 曰 katarzyna.smolny@ue.wroc.pl \\ (DD) orcid.org/0000-0001-5048-8372
}

MAEGORZTA GAEECKA

Wroclaw University of Economics and Business, Poland

$\square$ malgorzta.galecka@ue.wroc.pl

(D) orcid.org/0000-0003-1986-3140

\begin{abstract}
Motivation: The study of the problem of "cost disease" contributes to the possibility of creating a model for effective subsidy to cultural institutions operating in the field of performing arts from public funds. The study also forms a part of a broader reflection

on the values of culture, the humanism of culture and the economy in general.

Aim: This article is to examine the connection between productivity and labor costs in public theatres in Poland. We investigate what the level of productivity depends on. We check whether it is based on costs or the so-called income gap or another factor. We verify whether costs in PAOs in Poland increase according to the theory of Baumol's cost disease and whether labor costs are particularly significant in total costs.

Results: Labor costs should be taken into account when subsidizing performing art organizations, as productivity growth depends on having funds to cover labor costs and increasing employment.
\end{abstract}

Keywords: public sector; art organisations; theatres; culture; productivity JEL: H2; H7; H18 


\section{Introduction}

Baumol and Bowen (1966, p. 43) determined that a non-manufacturing sector, which includes PAOs, is more labor intensive than the dynamic manufacturing sector (Heilbrun, 2011, pp. 72). They predicted that productivity lag would increasingly make them dependent on subsidies. Subsequent studies indicated different variations in this area (Last \&Wenzel, 2010 , pp. 89-110; 2011, pp. 185201). In Europe, cultural institutions, including theatres, are mainly financed by public funds (Trupiano, 2005, p. 337). Productivity growth in the manufacturing sector contributes to overall wage growth in the economy. The natural consequence of this phenomenon is the pressure to increase salaries in PAOs, which affects the costs of their operation without any chance to increase productivity. The productivity and efficiency of public services are important from the point of view of its end-users (Musgrave, 1959, p. 84) and is the current trend of modern society (Gadrey, 2002, pp. 26-53). The article is intended to identify/seek ways of optimizing public funding of cultural entities while maximizing their public utility and is a part of the trend of seeking objective rules for the subsidy of cultural services (Thorsby, 2010, p. 28). Our study focuses on labor cost analysis in PAOs, assuming they are the primary cause of cost disease. We analyze the number of full-time equivalents (FTEs) and the total cost of their work. This analysis is carried out in terms of theatre productivity understood as an annual number of performances.

The purpose of this article is to examine the relationship between productivity, understood as a number of annual performances and costs, in particular labor costs. The following research questions were developed and analyzed for the purposes of the research objective:

1. Are labor costs related to theatre productivity as an annual number of performances?

2. Should the level of public theatre subsidies depend on labor costs, i.e. indirectly on the number of employees?

\section{Literature review}

The aim of the existence of Polish public theatres as artistic institutions is to "conduct and promote cultural activities" (Act on organizing and running cultural activities, 1991; Mituś, 2019, p. 5). In general, the mission of theatres is to disseminate culture as widely as possible (Hansmann, 1986, p. 22). Maintaining a constant or increasing level of supply of cultural services is, therefore, their primary objective (Snowball, 2008, p. 48). The support of performing arts by public funding is also generally recognized (Austin-Smith, 1980, pp. 9-17; Blanco et al., 2019, p. 97; Dalle Nogare \& Bertachini, 2015, p. 10; Musgrave, 1959 , p. 41). The system of financing PAOs in Poland and in many countries does not provide for objective rules and criteria for granting statutory subsidies (Zimnica-Kuzioła, 2017, p. 119). There are no optimal performance measures 
and the set level of funding (Gatecka \&Smolny, 2017, pp. 338-402). The level of subsidy depends mainly on the organizer (Trzeciak, 2011, p. 164). The most comprehensive analysis to date of the impact of government subsidies to the PAO was conducted by Netzer (1978, p. 62). He has demonstrated in his studies that the increase in public subsidies for theatres was linked to wage increase significantly above the increase in wages in the rest of the economy and supported the production increase in the form of season extension and stimulated artistic innovation. These conclusions are also confirmed by the studies carried out by Austin-Smith (1980, pp. 9-17). The author indicated evidence showing the impact of the subsidy on the level of basic artistic creation and the willingness of the management to produce new, often controversial or risky, productions, referred to by the author as ,lowbrow'. DiMaggio and Stenberg (1985, pp. 107-122) or J. O'Hagan and Neligan (2005, pp. 36-37) share their views in the same spirit. We took this measure of productivity on the basis of experience and established practice based on the literature (Fazioli \& Filippini, 1987, p. 77). In the literature, a premiere (production), theatrical performance (shows) or cultural experience of the viewer are considered to be the theatre service unit (Felton, 1994, p. 304). In the literature, there is also an indicator/concept of: "usability" as a function of the number of services, the number of tickets sold (Thorsby, 1994, p. 9) or the number of viewers (Thorsby \& Withers, 1979, p. 17; Trzeciak, 2011, p. 164). Obviously, it is impossible to measure the effects of theatre activity in quantitative terms only - the literature repeatedly stresses the importance of the qualitative criteria (Baldin et al., 2018, p. 678; O'Hagan \& Neligan, 2005, pp. 36-37; Thorsby, 1994, p 9; Thorsby \& Withers, 1979, p. 17; Trzeciak, 2011, p. 164). The number of performances we have assumed is a measure of the product, not demand (Felton, 1994, p. 304). In other research papers, we focus on measuring demand and availability (Gatecka \& Smolny, 2019, pp. 119-136).

The number of performances we have assumed is a measure of the product, not demand. In other research papers, we focus on measuring demand and availability.

The subject of the study covers public theatres in Poland for which their organizer is the city (or town with the administrative rights of a county) - municipal theatres. The data for the study were obtained by way of individual queries concerning the financial statements and substantive reports of cultural institutions for the years 2011-2015 (Buchwald, 2016). The study does not cover all Polish public theatres due to a lack of available data. The data was collected from 32 theatres, which represents almost half of the city theatres in Poland in 2015. Basic statistics in the field of culture for Poland were taken from the Local Data Bank of the Polish Central Statistical Office. 


\section{Materials and methods}

The relationship between the theatre financial data and their content data, such as the number of performances, the level of employment and the number of premieres (night shows) was examined to achieve the research objective. As regards the financial data, theatre revenues were of importance, including statutory subsidies and own revenues, as well as the costs of the theatres: remuneration, including statutory liabilities connected with remuneration or materials and energy consumption. The research period covers years 2011-2015.

The sample comprises a total of 32 municipal public theatres with at least one professional active team and at least one permanent stage. We divided this group into two subgroups. In the first sub-group, we included theatres whose statutory subsidy was lower than the annual labor costs. The second group includes theatres, whose statutory grant was equal to or higher than annual labor costs. The division into the subgroups mentioned above was based on the appropriate development of the statutory subsidy level in relation to labor costs in the majority of the years under examination. During the five-year study period under review, we adopted the value of three years or more. Both groups comprise of so-called small theatres in terms of the employment level (up to 50 FTEs) and large theatres (over 50 FTEs). Also, in both groups, there were theatres with different artistic repertoire (puppet, dramatic or musical theatres). The purpose of this division was to examine whether there were specific differences in the parameters analyzed. We consider both the cost of permanent staff and other costs - statutory liabilities concerning remuneration and work outsourced on a contract basis. Labor costs include the costs of all employees, i.e. both directly and indirectly linked to the ,production' of performances. Only personnel costs were taken into account to indicate the annual average salary (for permanent staff).

The authors used a correlation coefficient $\left(r_{s}\right)$ and medium-period tempo of change $(\bar{r})$ to examine the relationship between data.

$$
r_{s}=1-\frac{6 \sum_{i=1}^{n} d_{i}^{2}}{n\left(n^{2}-1\right)},
$$

where:

$$
d_{i}=r g\left(X_{i}\right)-r g\left(Y_{i}\right),
$$

is the difference between the two ranks of each observation; $n$ is the number of observations.

$$
\bar{r}=\bar{g}-1,
$$


where:

$$
\bar{g}=\sqrt{\frac{y_{2}}{y_{1}} \cdot \frac{y_{3}}{y_{2}} K \frac{y_{n-1}}{y_{n-2}} \cdot \frac{y_{n}}{y_{n-1}}}=\sqrt[n-1]{\prod_{i=2}^{n} \frac{y_{i}}{y_{i-1}}} .
$$

\section{Results}

Our study produced results in terms of: the tempo of change regarding labor costs and the number of annual performances, the relationship between cost-productivity correlation, productivity-grant correlation, and grant-own revenues correlation.

An in-depth analysis of the cost structure allowed for a comparison of the cost components in the theatres under consideration and an indication of the share of their individual elements in relation to the total costs. A growing trend of nominal total costs in all theatres surveyed is noticeable. Labor costs, which are the largest part of and have the biggest influence on the level of costs, account for about $85 \%$ of all costs. This percentage has increased since 2009. It was then estimated at $65 \%$ and a steady decrease in employment followed (Płoski, 2009, p. 28). The second-largest cost item was based on the other costs, while the consumption of materials and energy was on the third position. During the period considered, in 2012 only a decrease in labor costs in nominal terms could be seen, although their share in the overall cost structure increased. In the remaining years, there is a steady increase in expenditure for remuneration. The high percentage of remuneration in the running costs of the theatre may give rise to an allegation of an excessive number of full-time employees in theatres. However, it should be noted that a permanent team is a characteristic model of Polish theatres (and not only). Furthermore, in smaller cities, permanent teams are an important element of cultural activity. Moreover, the predominance of personnel costs in total costs is a phenomenon typical for performing arts - in accordance with Baumol's law (O'Hagan \& Neligan, 2005, pp. 36-37) (chart 1).

The study shows that there is a small percentage of own revenue in the artistic institutions under consideration, but a very high percentage of the subsidy from the organiser. The average percentage of own revenues in individual years was $26 \%$. The distribution of investigated values in individual years is similar. Own revenue partially covered the costs of the program /statutory activity and current activity, including mainly premieres. They are a significant complement to the financing by statutory grants, the percentage of which in total revenues averaged over $60 \%$. The revenue generated in many theatres analysed did not allow the costs incurred to be covered, thus creating an income gap. Any lack of adequate funds, in particular subsidies, is a lack of money either for salaries for actors or for new productions. Without adequate funding, it is difficult to talk about the essence of the theatre activity, although it is certainly cheaper. The research proves that the amount of statutory subsidy granted in 18 of 32 in- 
vestigated theatres is lower than the annual labour costs together with statutory liabilities related to permanent staff and other seasonal and/or contractual employees. This means that more than half of the theatres surveyed were obliged to finance not only the basic activities of the theatre but also the provision of remuneration funds. Table 1 presents the relationship between the level of subsidies and the level of labour costs in these theatres.

The average tempo of change in the years 2011-2015 provided information on the average change in labor costs and the number of annual performances. The results obtained show significant differences between the investigated groups of theatres (table 2). The scale of these differences is also important.

For the group of theatres, where the subsidy did not cover the costs of remuneration, labor costs increased by 0.98 per year on average. In the theatre group, where the grant was equal to or higher than labor costs, the increase was significantly higher and amounted to 4.11 per year. In turn, the number of performances, for the group of theatres with subsidies lower than labor costs, increased by 0.67 per year on average. While in theatres with subsidies equal to or above labor costs, this increase was 5.27. By comparing the analysis results in the two groups of theatres, we immediately see how important the scale of the pace of growth in both costs and the number of performances is. These differences have a significant effect on the number of performances; and the latter, in turn, has a significant effect on own revenues generated by cultural institutions.

There is a very strong correlation between the statutory subsidy and labor costs in each of the two groups of investigated theatres. A stronger correlation (97) is seen in the group of theatres, whose annual statutory subsidy was higher than labor costs. In the theatres where the subsidy was lower than annual labor costs, the correlation was 81 . This means that as the statutory subsidy increases, labor costs also increase. At the same time, it is logical to have a stronger link between subsidies and labor costs in theatres, where public funds can cover these costs. With a grant covering labor costs, the theatre manager "does not save on employees" - less often employs seasonal workers, can afford a permanent team or teams, and also can employ stars.

A similar situation is apparent in the context of statutory subsidies and the use of materials and energy. Theatres, where the subsidy was higher or equal to labor costs, showed a stronger relationship (70) than in those where the costs were higher than the subsidy (48). Although there are deviations in the correlation coefficient, it should be noted that the relationship between the two investigated groups is positive.

A strong link between the subsidy and labor costs is also important for maintaining the stability of the theatre team. During the period considered, a decrease in the number of FTEs in the two groups of theatres examined (see table 1) can be observed. This decrease occurred in more theatres, where the level of subsidy received was lower than labor costs. In the case of a group of theatres with a higher subsidy than labor costs, the decrease in the number of FTEs 
took place only in half of the units. It is worth considering whether the increase in labor costs did not result in the removal of full-time positions in a conscious or subconscious effort to ensure financial stability for the theatre.

Wage pressure in the economy as a key factor in the cost disease is a consequence of an increase in the average wage level in the economy or GDP. An analysis of the dynamics of remunerations in theatres showed that from 2013 onwards salaries increased at a faster pace than the level of prices in the economy. At that time, GDP in Poland grew and what followed was an increase in the average wage in the economy. In addition, despite zero inflation in Poland in 2014 and deflation in 2015, more than 69 of the theatres surveyed were subject to an increase in real remuneration. It is worth pointing out that in small theatres (up to 50 FTEs) the average annual, remuneration per full-time equivalent' does not differ significantly from the average of ,remuneration per full-time equivalent' in large theatres (over 50 FTEs). The median annual labor costs of FTEs in small theatres are even higher than the median for large theatres. The standard deviation between the investigated theatres (small and large) was on average about PLN 12 thousand per year. This means that regardless of the size of the theatre, the cost disease is the same for small theatres as for large theatres. More importantly, the study did not show a significant link between the level of labor costs of employees and theatre productivity we are examining, i.e. the annual number of performances. The results of the correlation for the group of theatres where the subsidy did not fully cover labor costs were statistically insignificant $(\mathrm{r}=-0.16)$, while for the next group of theatres the correlation was moderate $(r=-0.35)$. The reasons for such results may be sought in the low sample size or in its possible non-representativeness. At this stage of the study, it should be noted that the number of performances in the theatres examined was not related to labor costs. In other words, theatre productivity is not correlated with remuneration increases. However, it should be stressed that in both groups, the correlations were negative. Given the average annual remuneration of permanent staff only, it can be noted that despite the increase in expenditure for their remuneration, the number of performances did not change substantially (chart 2). In many theatres - Teatr Łaźnia Nowa, Teatr Baj, Teatr Scena Prezentacje, Teatr Powszechny, Teatr Rampa or Teatr Syrena - despite the increase in the average annual remuneration for the staff, the number of performances decreased.

Like labor costs, the grant itself did not translate into theatre productivity, i.e. the annual number of performances. Due to the low correlation coefficient, there is virtually no link between the subsidy and the number of productions. However, there is a moderate correlation between the number of performances and the number of FTEs $(r=44)$. This value applies only to the group of theatres with subsidies equal to or greater than labor costs. We conclude that theatres with funds provided for remunerations do not have to make a choice between paying salaries and carrying out subsequent productions. All the more so, apart from the permanent staff, theatres employ many external (non-perma- 
nent) employees. Especially during large events, presence of additional people in the theatre is necessary, so this undoubtedly affects the total costs borne by the institution. With limited funds, the theatre will not be able to recruit new staff, whose presence is essential for the production of shows. Consequently, the theatre will not be able to make new productions, which will affect the theatres' own revenues essentially.

The research confirmed a very strong link $(r=76)$ between the subsidy and theatres' own revenues. However, it needs to be emphasized that such a high correlation coefficient occurred only in the group of theatres where public funding was higher or equal to labor costs. This is in line with existing research into the impact of grants on efficiency in financial terms (Gilhespy, 1999, p. 125).

As shown above, there is no direct material link between the subsidy and the number of performances and thus the productivity of the theatre. Yet, it translates into an increase in theatre's own revenues while reducing the income gap. However, this is only noticeable in one theatre group in question, where the statutory subsidy was equal to or higher than labor costs. Theatres which had to pay (in part) the wage costs and the costs of consumed materials and energy (in full) from their own revenues were unable to afford more productions.

\section{Conclusion}

High productivity plays an important role in theatre economic activities, both culturally and economically. On the one hand, it maintains a high level of supply of cultural services, and on the other hand, it represents a significant income from its own revenues. In the years analyzed an upward trend in the number of performances in most of the theatres in question can be seen. An average annual tempo of change in the number of performances in both groups investigated is positive. However, a significant increase is noticeable in one group only, namely in those theatres, where the grant was higher or equal to labor's costs. In addition, in this group of theatres, the tempo of rising labor's costs was lower than the tempo of raising the theatre's productivity. In the second group of theatres, the advantage of rising labor's costs over rising of productivity is noticeable. In other words, labor's costs increase at a faster pace than productivity in the group of theatres, where the subsidy was lower than labor's costs. The increase in remuneration alone remained unconnected with productivity. This has been confirmed by the low correlation coefficient between salary and productivity. At the same time, they point out that wage pressure in Poland is low. Also, the correlation between the level of subsidies and the number of performances bears little relation. However, the grant was indeed related to costs, including labor's costs and own revenues, in particular. A stronger relationship occurred in one group of investigated theatres only where the grant was higher or equal to labor's costs. In the second study group, this relationship was weaker and, in relation to own revenues, it was even marginal. 
It follows from the above considerations that subsidising theatres had a major impact on productivity growth. This is not about the subsidies as such, but about "effective" (optimal) subsidies for theatres. Research showed that a statutory subsidy based on labor's costs is a crucial element for increasing the productivity of theatres. Ensuring the level of subsidies to theatres (at least equal to labor's costs) should be a part of providing the supply of services to potential viewers in such an important discussion on the availability of cultural goods. On the other hand, it would foster the management of human resources in theatres. In the absence of any increase in labor productivity within arts, adequate funding and with increasing wage pressure, the gap between income and costs is constantly growing (Nierenberg, 2009, p. 22). Thus, although the productivity of theatres remains unchanged, salaries must increase. The statutory subsidy is important here. An increase in labor costs, in the absence of adequate funding, ultimately could lead to a widening of the ,artistic deficit' (Schulze, 2011, p. 188) (in the artistic goods market). It is illustrated by the decrease in the number of FTEs in many of the theatres we have been investigating. This decline is more pronounced in the group of theatres where grants did not provide full labor cost financing.

\section{References}

Austin-Smith, D. (1980). On the impact of revenue subsidies on reporter theatre policy. Journal of Cultural Economics, 4, 9-17. https://doi.org/10.1007/ BF00240641.

Baldin, A., Bille, T., Ellero, A., \& Favaretto D. (2018). Revenue and attendance simultaneous optimisation in preforming arts organisations. Journal of CulturalEconomics, 42, 677-700. https://doi.org/10.1007/s10824-018-9323-7.

Baumol, W.J., \& Bowen, W.G. (1966). Performing arts: the economic dilemma: a study of problems common to theater, opera, music, and dance. MIT Press.

Blanco, F., Rodriguez-Alvarez, V., \& Wisniewska, A. (2019). Measuring technical efficiency and marginal costs in the performing arts: the case of the municipal theatres of Warsaw. Journal of Cultural Economics, 43, 97-119. https:// doi.org/10.1007/s10824-018-9330-8.

Buchwald, B. (Ed.). (2016). Teatr w Polsce: dokumentacja sezonu 2014/2015. Retrieved 10.10.2020 from https://encyklopediateatru.pl/ksiazka/702/ teatr-w-polsce-2016-dokumentacja-sezonu-20142015.

Dalle Nogare, C., \& Bertacchini, E. (2015). Emerging modes of public cultural spending: direct support through production delegation. Poetics, 49, 5-19. https://doi.org/10.1016/j.poetic.2015.02.005.

DiMaggio, P., \& Stenberg, K. (1985). Why do some theatres innovate more than others: an empirical analysis. Poetics, 14(1-2), 107-122. https://doi. org/10.1016/0304-422X(85)90007-5. 
Fazioli, R., \& Filippini, M. (1987). Cost structure and product mix of local public theatres. Journal Cultural Economics, 21, 77-86. https://doi. org/10.1023/a:1007341613767.

Felton, M.V. (1994). Evidence of the existence of the cost disease in the performing arts. Journal of Cultural Economics, 18, 301-312. https://doi.org/10.1007/ bf01079761.

Gadrey, J. (2002). The misuse of productivity concepts in services: lessons from a comparison between France and the United States. In J. Gadrey, \& F. Gallouj (Eds.), Productivity, innovation and knowledge in services (pp. 26-53). Edward Elgar.

Gałecka, M., \& Smolny, K. (2017). Financing rules of the activity of cultural institutions in the context of economic efficiency. Ekonomia i Prawo. Economics and Law, 16(4), 387-399. https://doi.org/10.12775/eip.2017.027.

Gałecka, M., \& Smolny, K. (2019). Criteria for the optimal financing model of public theatres. Review of Economic Perspectives, 19(2), 119-136. https:// doi.org/10.2478/revecp-2019-0007.

Gilhespy, I. (1999). Measuring the performance of cultural organisations: a model. International Journal of Arts Management, 2(1), 38-52.

Hansmann, H. (1986). Nonprofit enterprise in the arts: studies in mission and constraint. Oxford University Press.

Heilbrun, J. (2011). Baumol's cost disease. In R. Towse (Ed.), A handbook of cultural economics (2nd edition) (pp. 67-75). Edward Elgar. https://doi.org/10 $.4337 / 9780857930576.00016$.

Last, A.K., \& Wetzel, H. (2010). The efficiency of German public theaters: a stochastic frontier analysis approach. Journal of Cultural Economics, 34, 89-110. https://doi.org/10.1007/s10824-009-9111-5.

Last, A.K., \& Wetzel, H. (2011). Baumol's cost disease, efficiency, and productivity in the performing arts: an analysis of German public theaters. Journal of Cultural Economics, 35(3), 185. https://doi.org/10.1007/ s10824-011-9143-5.

Mituś, A. (2019). Tworzenie i funkcjonowanie państwowych i samorządowych instytucji kultury. In Vademecum dyrektora instytucji kultury (pp. 3-19). C.H. Beck.

Musgrave, R. (1959). The theory of public finance: a study in public economy. McGraw Hill.

Netzer, D. (1978). The subsidised muse: public support for the arts in the United State. Cambridge University Press.

Nierenberg, B. (2009). Economic premises of culture management. Culture Management, 2(2), 20-24.

O'Hagan, J., \& Neligan, A. (2005). State subsidies and repertoire conventionality in the non-profit English theatre sector: an econometric analysis. Journal of Cultural Economics, 29, 35-57. https://doi.org/10.1007/ s10824-005-8132-y. 
Płoski, P. (2009). Przemiany organizacyjne teatru w Polsce $w$ latach 1989-2009. Retrieved 01.10.2020 from http://www.kongreskultury.pl/library/File/ RaportTeatr/teatr_raport_w.pelna(l).pdf.

Schulze, G.G (2011) International trade. In R. Towse (Ed.), A handbook of cultural economics (2nd edition) (pp. 236-244). Edward Elgar. https://doi.org/ $10.4337 / 9780857930576.00039$.

Snowball, D. (2008). Measuring the value of culture: methods and examples in cultural economics. Springer. https://doi.org/10.1007/978-3-540-74360-6.

Thorsby, D. (1994) The production and consumption of the arts: a view of cultural economics. Journal of Economic Literature, 32(1), 1-29.

Thorsby, D. (2010). The economics of cultural policy. Cambridge University Press. https://doi.org/10.1017/CBO9780511845253.

Thorsby, D., \& Withers, G.A. (1979). The economics of the performing arts. Edward Arnold.

Trupiano, G. (2005) Financing the culture in Italy. Journal of Cultural Heritage, 6(4), 337-343. https://doi.org/10.1016/j.culher.2005.04.004.

Trzeciak, H. (2011). Ekonomiczne determinanty poziomu dziatalności artystycznej teatrów dramatycznych w Polsce. Retrieved 01.10.2020 from https://www. nck.pl/upload/archiwum_kw_files/artykuly/hanna_trzeciak_-_ekonomiczne_determinanty_poziomu_dzialalnosci_artystycznej_teatrow_ dramatycznych_w_polsce.pdf.

Ustawa z dnia 25 października 1991 r. o organizowaniu i prowadzeniu działalności kulturalnej [Act of October 25, 1991 on organizing and running cultural activities] (Dz.U. $1991 \mathrm{nr} 114$ poz. 493) (Poland).

Zimnica-Kuzioła, E. (2017). Polityka teatralna w Polsce po transformacji ustrojowej. Annales Universitatis Mariae Curie-Sklodowska, Sectio L: Artes, 15(2), 111-126. https://doi.org/10.17951/1.2017.15.2.111.

\section{Acknowledgements}

Author contributions: authors have given an approval to the final version of the article. Authors contributed to this work equally.

Funding: this research was fully funded by the Wroclaw University of Economics and Business.

Note: the results of this study were presented at the 8th International Conference Sustainable Finance \& Accounting: Economy, Ethics, Environment (April 19-21, 2021, Toruń, Poland). 


\section{Appendix}

Table 1.

Subsidies of the theatres surveyed to gross annual labor costs in 2011-2015 (\%)

\begin{tabular}{|c|c|c|c|c|c|c|c|}
\hline No & FTE $^{*}$ & Theatres & 2011 & 2012 & 2013 & 2014 & 2015 \\
\hline \multicolumn{8}{|c|}{ Theatres where the subsidy was lower than the labor cost } \\
\hline 1. & 88.97 & Teatr Ludowy & 86 & 89 & 87 & 83 & 89 \\
\hline 2. & 116.00 & Teatr Bagatela & 54 & 54 & 51 & 58 & 63 \\
\hline 3. & 88.00 & Teatr Nowy im. K. Dejmka & 108 & 95 & 89 & 95 & 97 \\
\hline 4. & 51.80 & Teatr Powszechny & 105 & 100 & 90 & 93 & 95 \\
\hline 5. & 56.00 & Teatr Lalek Arlekin & 105 & 92 & 93 & 89 & 97 \\
\hline 6. & 53.20 & Teatr Lalki i Aktora Pinokio & 103 & 99 & 85 & 90 & 106 \\
\hline 7. & 155.00 & Teatr Muzyczny & 111 & 100 & 91 & 97 & 95 \\
\hline 8. & 97.20 & Teatr Ateneum im. S. Jaracza & 101 & 97 & 101 & 94 & 95 \\
\hline 9. & 38.00 & Teatr Lalek Guliwer & 97 & 88 & 86 & 81 & 88 \\
\hline 10. & 23.35 & Północne Centrum Sztuki & 42 & 10 & 13 & 36 & 50 \\
\hline 11. & 59.85 & Teatr Kwadrat & 25 & 39 & 16 & 9 & 56 \\
\hline 12. & 41.00 & Teatr Lalka & 106 & 92 & 87 & 98 & 102 \\
\hline 13. & 44.05 & Teatr Nowy & 93 & 99 & 88 & 80 & 131 \\
\hline 14. & 60.24 & Teatr Rampa na Targówku & 86 & 74 & 79 & 86 & 96 \\
\hline 15. & 49.25 & Teatr Muzyczny Roma & 65 & 57 & 60 & 118 & 99 \\
\hline 16. & 51.63 & Teatr Syrena & 73 & 67 & 86 & 82 & 90 \\
\hline 17. & 95.00 & Teatr Współczesny & 96 & 96 & 94 & 91 & 93 \\
\hline 18. & 72.50 & Teatr Żydowski im. E., R., I. Kamińskich & 81 & 83 & 83 & 20 & 89 \\
\hline \multicolumn{8}{|c|}{ Theatres where the subsidy was higher or equal to the labour cost } \\
\hline 1. & 70.45 & Teatr Polski im. H. Konieczki & 109 & 110 & 114 & 110 & 123 \\
\hline 2. & 53.00 & Teatr im. W. Gombrowicza & 134 & 124 & 98 & 104 & 99 \\
\hline 3. & 70.70 & Teatr Groteska & 95 & 101 & 101 & 109 & 107 \\
\hline 4. & 24.86 & Teatr Łaźnia Nowa & 96 & 129 & 122 & 130 & 178 \\
\hline 5. & 45.50 & Teatr im. H.Ch. Andersena & 111 & 128 & 114 & 107 & 111 \\
\hline 6. & 31.75 & Teatr Baj & 107 & 103 & 101 & 106 & 107 \\
\hline 7. & 137.60 & Teatr im. G. Holoubka & 115 & 123 & 133 & 123 & 126 \\
\hline 8. & 14.75 & Teatr Ochoty & 88 & 85 & 102 & 134 & 117 \\
\hline 9. & 71.82 & Teatr Rozmaitości & 115 & 109 & 111 & 119 & 130 \\
\hline 10. & 11.02 & Teatr Scena Prezentacje & 102 & 96 & 100 & 125 & 117 \\
\hline 11. & 92.00 & Teatr Studio im. S.I. Witkiewicza & 135 & 114 & 103 & 108 & 114 \\
\hline 12. & 45.50 & Teatr Maska w Rzeszowie & 111 & 124 & 123 & 110 & 109 \\
\hline 13. & 8.25 & Teatr Kto & 102 & 115 & 88 & 154 & 130 \\
\hline 14. & 95.25 & Teatr Powszechny im. Z. Hübnera & 101 & 100 & 100 & 108 & 106 \\
\hline
\end{tabular}

Notes:

* Grey cells — FTEs was lower than in 2011; standard black — FTEs was higher than in 2011; bold — FTEs was the same as in 2011.

Source: Own preparation based on reports of cultural organizations from years 2011-2015. 
Table 2 .

Medium-period tempo of change for annual labor costs and number of performances in 2011-2015

Research group

theatres: statutory subsidy was lower than the annual labor costs

theatres: statutory subsidy was equal to or higher than annual labor costs

Labor costs Number of performances

$0.98 \quad 0.67$

4.11 5.27

Source: Own preparation.

\section{Chart 1.}

Average structure of revenues and costs in the theatre's studies (\%)

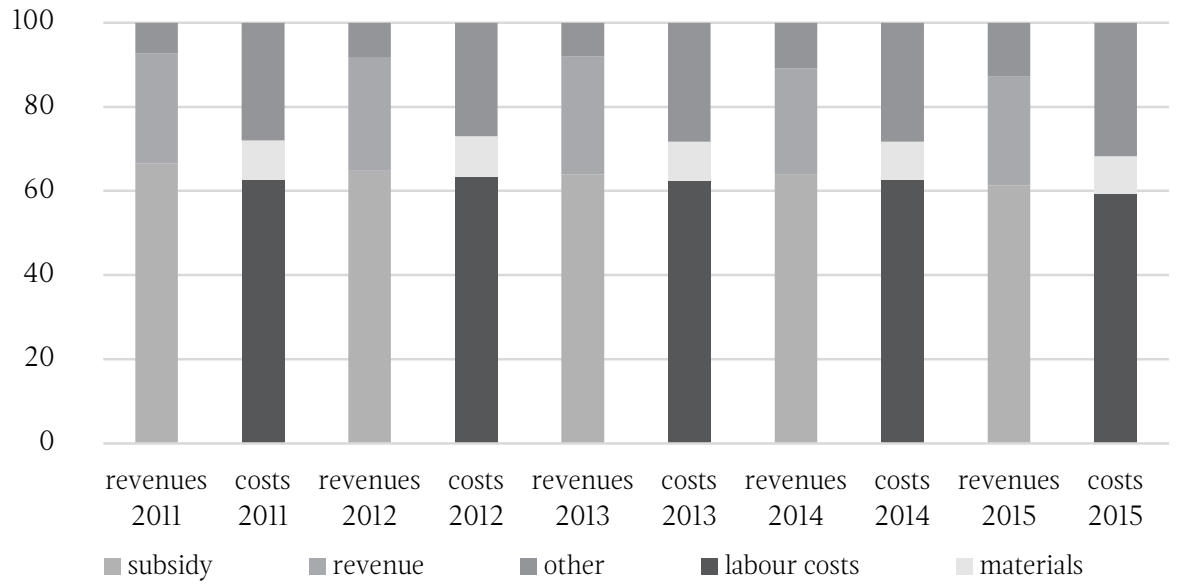

Source: Own preparation. 


\section{Chart 2.}

Average annual employee remuneration (PLN) versus a number of performances in 2011 and 2015

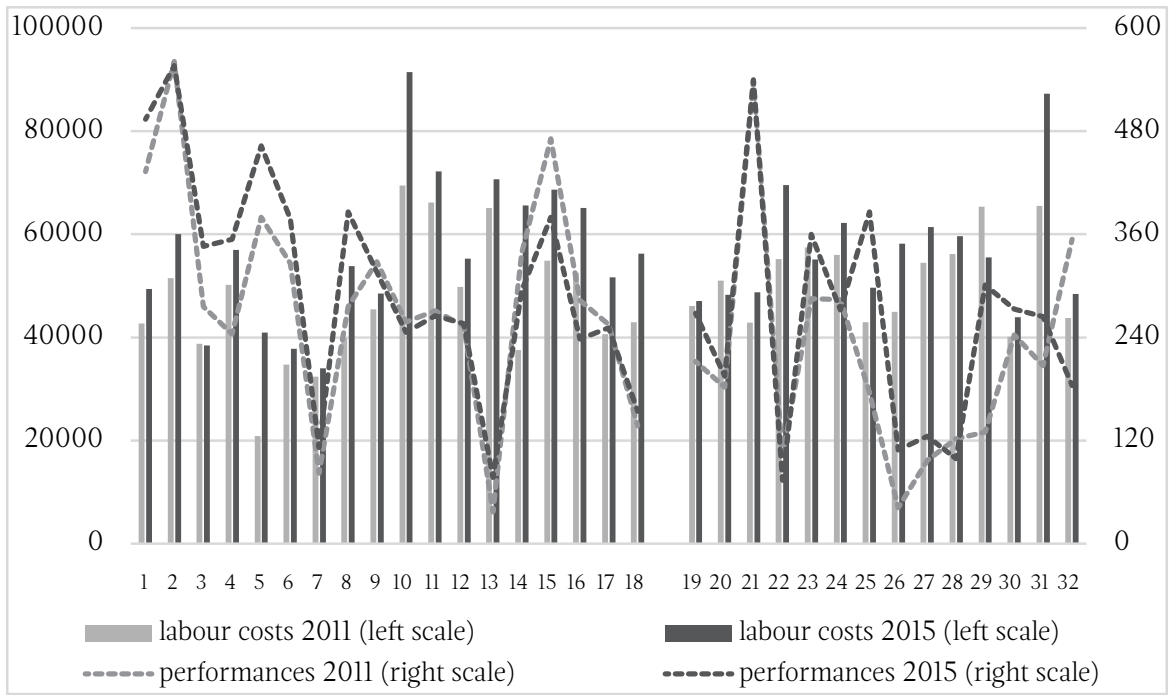

Notes:

1 - Teatr Ludowy; 2 - Teatr Bagatela im. T. Boya-Żeleńskiego; 3 - Teatr Nowy im. K. Dejmka; 4 - Teatr Powszechny; 5 - Teatr Lalek „Arlekin”; 6 - Teatr Lalki Aktora „Pinokio”; 7 - Teatr Muzyczny; 8 - Teatr Ateneum im. S. Jaracza; 9 - Teatr Lalek Guliwer; 10 - Północne Centrum Sztuki Teatr Komedia; 11 - Teatr Kwadrat; 12 - Teatr Lalka; 13 - Teatr Nowy; 14 - Teatr Rampa na Targówku; 15 - Teatr Muzyczny Roma; 16 - Teatr Syrena; 17 - Teatr Współczesny; 18 - Teatr Żydowski im. E., R. \& I. Kamińskich; 19 - Teatr Polski im. H. Konieczki; 20 - Teatr Miejski im. W. Gombrowicza; 21 - Teatr Lalki, Maski i Aktora „Groteska”; 22 - Teatr Łaźnia Nowa; 23 Teatr im. H.Ch. Andersena; 24 - Teatr Baj; 25 - Teatr Dramatyczny im. G. Holoubka; 26 - Teatr Ochoty; 27 - Teatr Rozmaitości; 28 - Teatr Scena Prezentacje; 29 - Teatr Studio im. S.I. Witkiewicza; 30 - Teatr „Maska” w Rzeszowie; 31 - Teatr Kto; 32 - Teatr Powszechny im. Z. Hübnera.

Source: Own preparation. 